\title{
The Relationship Between Prior Knowledge and Creative Thinking Ability in Chemistry
}

\author{
Dewi Satria Ahmar ${ }^{1,2,4^{*}}$, Ramlawati $^{2}$, Melati Masri ${ }^{2}$, and Ansari Saleh Ahmar ${ }^{3,4}$ \\ ${ }^{1}$ STKIP YAPTI Jeneponto, Jeneponto, Indonesia \\ ${ }^{2}$ Chemistry Department, Universitas Negeri Makassar, Makassar, Indonesia \\ ${ }^{3}$ Statistics Department, Universitas Negeri Makassar, Makassar, Indonesia \\ ${ }^{4}$ Ahmar Institute, Makassar, Indonesia
}

Accepted 25 July 2017

Educational Process: International Journal Volume 6, Issue 3, 2017

\begin{abstract}
This study aims to determine the relationship between prior knowledge with creative thinking ability of students in grade XI science at public school of Takalar. This research is ex post facto. The population in this research is was all students in grade XI science at public school of Takalar consisting of 39 classes with a total enrollment in 1537 people. Technique collecting sample using stratified purposive random sampling and selected grade XI Science SMAN 1 Takalar, SMAN 3 Takalar, SMAN 1 Polongbangkeng Selatan, and SMAN 3 Polongbangkeng Utara consist of 134 learners. The data was collected by using prior knowledge test consist of 16 items $(\alpha=0.883)$ and verbal creativity test consist of 18 items $(\alpha$ $=0.808)$. Data were analyzed using correlation and regression analysis, The coefficient correlation between the two variables is 0.619 with $\mathrm{p}=0.000(\mathrm{p}<0.05)$. This value indicates that there is a relationship between prior knowledge with creative thinking ability in chemistry and relationship between the two variables is a positive relationship.
\end{abstract}

Keywords: Prior knowledge; Creative thinking ability

\section{Introduction}

Creativity is indispensable for the development of a nation. With the creativity, every nation will have competitiveness with other nations. The Act No. 20 of 2003 on National Education System of Education explained that the goal is to develop students to become people of faith and fear of God Almighty, noble, healthy, knowledgeable, skilled, creative, independently, and become citizens of a democratic and accountable. Based of the Act it appears that one of the aspects that need to be developed in the educational process is the creativity of learners.

Based of the the National Education goals, it means that the development of creativity of learners is one part of teaching and learning in schools. Thus, chemistry as one of the subjects in school can be used as a part to develop the creativity of learners.

Creativity in learning chemistry among other things required in terms of completing challenging problems, problems related to the application of chemistry in everyday life, and the trials or experiments and scientific methods related to chemistry. This is consistent with the statement Mulyasa (2009) that the chemistry is 
a science that is included in the Natural Sciences clumps are identical to the trials or experiments, as well as other scientific methods that can provide experiences for learners to perform hypothesis testing by designing experiments through the installation of instruments, retrieval, processing, interpretation of data, and present the results of experiments orally and in writing. This statement shows that in studying chemistry, it takes creativity or creative thinking ability of students. Therefore creative thinking abilities can be developed through the study of chemistry, and it is one of the responsibilities of a teacher of chemistry is developing creative thinking skills of learners.

In general, chemistry teachers including in Takalar has made various efforts to develop creative thinking skills of learners, for example by using a variety of models and instructional media, such as problem-based learning model (problem based learning), and animated media in learning chemistry. However, the expected outcome is not maximized. This statement is supported by the data from one of the high schools in Takalar which showed that the average value of creative thinking abilities of students in the hydrocarbon material is 44.41. (documentation of SMAN 1 Galesong Utara, 2011).

Based of the state, to note that the efforts made by the teacher would be meaningless if the learner as a subject of study does not involve theirself or does not actively participate in the learning process. It means that, it takes a study of related variables or contribute to creative thinking ability of students.

The research was doing by Groncher et al. (2009) showed that prior ability contributed to the ability of learners to make new engineering design solution.

Prior ability can be defined as the ability possessed by learners who are used to facilitate the acquisition, organization, and rephrase the new knowledge (Sanjaya, 2012). Prior ability of each learner is different. These differences affect how they present, interpret, and manage information obtained. The differences in processing and integrating new information can influence them in remembering, thinking, applying, and creating new knowledge (Yaumi, 2013). Therefore the prior ability affect the ability of learners in thinking, it can be said that the prior ability determined the creative thinking ability of students.

Anwar and Rasool (2012) argues that everyone has differences creativity, background, motivation, ability, and differences in response. Because of these reasons, Anwar \& Rasool (2012) conducted a study comparing the ability of creative thinking of students of high and low achievers. The results showed that there was no difference in the ability of creative thinking among learners of high and low achievers, but the students are female and come from the town has the ability to think creatively better. The Results of Study by Groncher et al. (2009) and the opinion of Anwar \& Rasool (2012) can be a consideration to find the relationship between creative thinking ability and prior knowledge.

\section{Methodology}

\subsection{Types of Research}

Reviewed based on the data, the type of research conducted in this research is quantitative research. Based on this research, data retrieval is ex post facto research. 
Belongs to the ex post facto research because this research is used to explain the existence the relationship of each variable.

\subsection{Population and Sample}

The population in this research were all students of grade XI Science of High School State in Takalar Regency in the academic year 2013/2014, consist of 1537 students. Sampling was done through purposive stratified random sampling technique. This sampling technique was choosen because the population is not homogeneous and stratified for several high schools in Takalar and it divided into excellent and not excellent school and are at different locations within the city and outside the city. In order to research data more representative of the population selected to represent the two schools within the city and two school outside the city. The Department of Education, Culture, Youth and Sports Takalar obtained that the school is located in the city are excellent schools and schools that outside of city is not an escellent school. Thus, the sample of this study was SMAN 1 Takalar, SMAN 3 Takalar, SMAN 1 Polongbangkeng Selatan, and SMAN 1 Polongbangkeng Utara. From each school were selected Grade XI Science 1 as sample. Reasons for the selection of the sample is due to any existing SMA Takalar determine grade students based on their ability level. Thus the number of samples in this study were 134 people.

\subsection{Research Variables}

The variable in this study is the prior ability and creative thinking ability in chemistry. Prior ability is the prerequisite knowledge possessed by students to learn the concepts of acid-base measured using a cognitive test that includes the ability to remembering $(\mathrm{C} 1)$, understanding $(\mathrm{C} 2)$, and applying $(\mathrm{C} 3)$. Creative thinking ability of students is the ability of learners in completing verbal creativity test which is based on the cognitive dimension includes: fluency, flexible, original and elaboration thinking.

\subsection{Research Instruments}

Instrument in this study consisted of prior ability tests, and tests of verbal creativity. Test of the prior ability arranged in the form of multiple choice which includes materials related to the acid-base concept is the material of the periodic system and atomic structure, reaction rate, and chemical equilibrium. Verbal creativity test arranged in a essay test that consists of six sub-tests that test the beginning of the word, arrange words, forming sentences of three words, the same properties, to various uses, and what the consequences. Sub-tests are taken as the basis to determine the ability of creative thinking of learners that includes the ability to fluency, flexibility, original and elaborate thinking. Validity test was done by using the content validity and the empirical validity. Content Validity done by appealing to two experts about the appropriateness of indicators and instruments developed grains, whereas the empirical validity of the tests carried out with the instrument at one of the schools that the population and are not included in the study sample, and 
then conducted a factor analysis technique using product moment correlation. Realiabilitas test using Alpha Cronbach formula.

After having tested the validity and reliability testing, it is known that the prior ability tests used in the study consisted of 16 items with Cronbach alpha reliability coefficient was 0.883 . Meanwhile, the verbal creativity test used 18 items with Cronbach alpha reliability coefficient was 0.808 .

\subsection{Data Analysis Techniques}

The data obtained in this study were analyzed using the technique of Pearson product moment correlation and regression analysis. Technique of the Pearson product moment correlation was used to test the hypothesis, and regression analysis is used to determine the contribution of prior ability on the ability of creative thinking in chemistry.

\section{Result and Discussion}

\subsection{Research Result}

\subsubsection{Description of student prior Ability}

The result of descriptive analysis for prior ability indicates that the prior ability learners in Takalar have a minimum score of 6, maximum score of 100, an average score of 53.5, median 50, mode 38, and a standard deviation of 26.7. The results of a descriptive analysis of the prior ability of students is presented in Table 1.

The distribution of data frequency by category of prior ability low, middle, and high can be seen in Table 2. In the table, it appears that the highest frequency of prior ability that is 71 learners in the middle category. Therefore, it can be concluded that in general, the prior ability learners in Takalar is in the middle category.

Description of the average value for each aspect of the prior knowledge can be seen in Table 3. In this table can be seen that the aspect understanding (C2) setting has the highest score. More clearly, the average value for each aspect for every school can be seen in

Table 1 Descriptive Statistic of Students Prior Ability

\begin{tabular}{lc}
\hline \multicolumn{1}{c}{ Statistic } & Statistic Score \\
\hline Minimum score & 6 \\
Maximum score & 100 \\
Ideal score & 100 \\
The mean score & 53,5 \\
Median & 50 \\
Modus & 38 \\
Standard deviation & 26,7 \\
\hline
\end{tabular}


Table 2 Frequency Distribution of Students Prior Ability

\begin{tabular}{lcc}
\hline \multicolumn{1}{c}{ Kategori } & Interval & Frekuensi \\
\hline Low & $<26,7$ & 30 \\
Middle & $26,7-80,2$ & 71 \\
High & $>80,2$ & 33 \\
\hline
\end{tabular}

Table 3 Average Value of Each Aspect of Prior Ability

Aspect of prior ability Average value

\begin{tabular}{lr}
\hline Remembering (C1) & 9,8 \\
Understanding (C2) & 28,5 \\
Applying (C3) & 13,7 \\
\hline
\end{tabular}

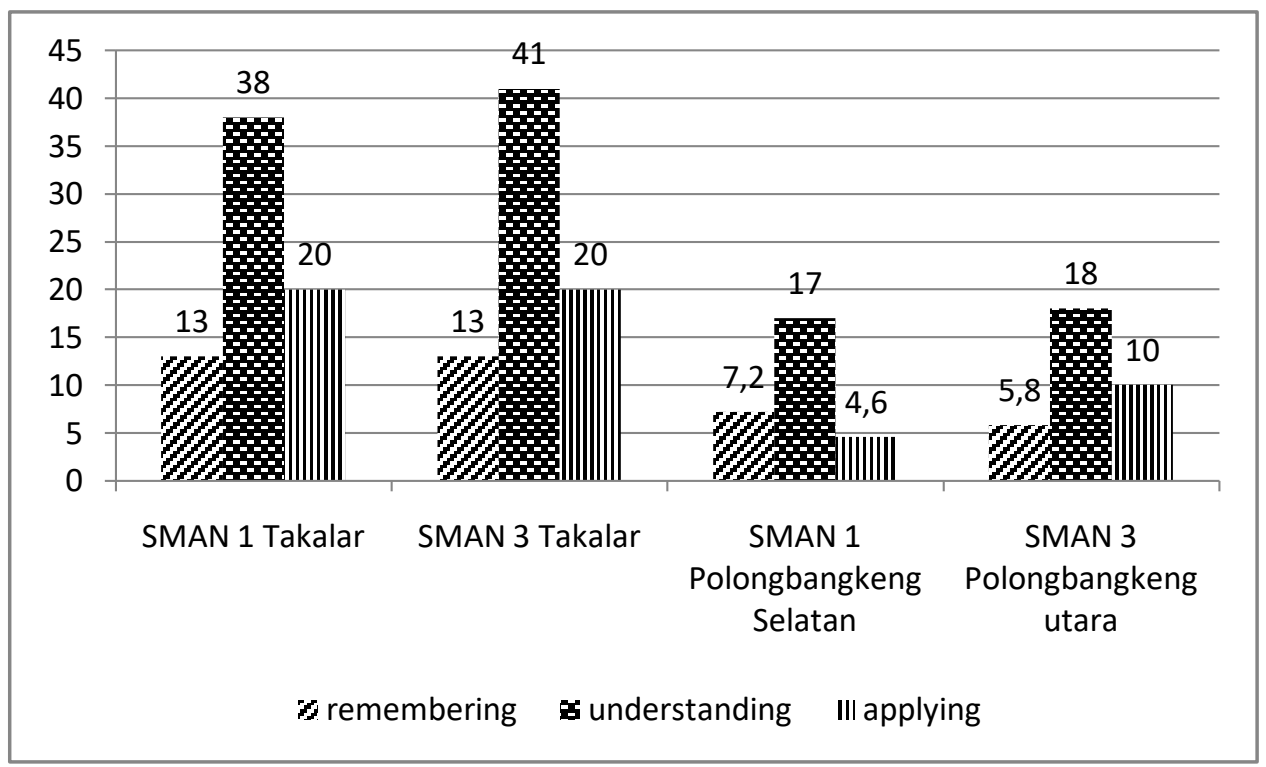

Figure 1. Average value of each aspect of prior ability for every school

\subsubsection{Description of creative thinking ability of students}

The results of the descriptive statistical analysis of creative thinking ability of students through verbal creativity tests indicate that a minimum score of 16 , a maximum score of 93 , an average score of 48.6 , median 42 , mode 20 , and a standard deviation of 23.9. The results of the analysis of creative thinking ability of students based on verbal creativity tests are presented in Table 4 .

The frequency distribution of creative thinking ability through verbal creativity tests by categories of low, middle, and high can be seen in Table 5. In the table, it 
appears that the highest frequency of creative thinking skills through verbal creativity test which 82 are in the middle category. So it can be concluded that in general, the creative thinking ability the learers in Takalar in middle category.

Description of the average value for each aspect of the verbal creative thinking abilities can be seen in Table 6. In the table, can be seen that aspect fluency of thinking has the highest average. More clearly, the average value for each aspect of the creative thinking abilities at each school t can be seen in Figure 2.

Table 4. Descriptive Statistics Creative Thinking Ability of Students

\begin{tabular}{lc}
\hline \multicolumn{1}{c}{ Statistcs } & Statistic Score \\
\hline minimal Score & 16 \\
Average Score & 48,6 \\
Median & 42 \\
Mode & 20 \\
Standard deviation & 23,9 \\
\hline
\end{tabular}

Table 5 Frequency Distribution of Students Creative Thinking Ability

\begin{tabular}{lcc}
\multicolumn{1}{c}{ Category } & Interval & Frekuency \\
\hline Low & $<90,058$ & 32 \\
Moderate & $90,058-124,42$ & 82 \\
Height & $>124,42$ & 20 \\
\hline
\end{tabular}

Table 6 Average Value Aspects of Creative Thinking

\begin{tabular}{lc}
\hline \multicolumn{1}{c}{ Aspect of creative thinking } & Nilai Rata-Rata \\
\hline Fluency of thinking & 36 \\
Flexibility and original of thinking & 7,7 \\
Elaborate of thinking & 2,5 \\
\hline
\end{tabular}

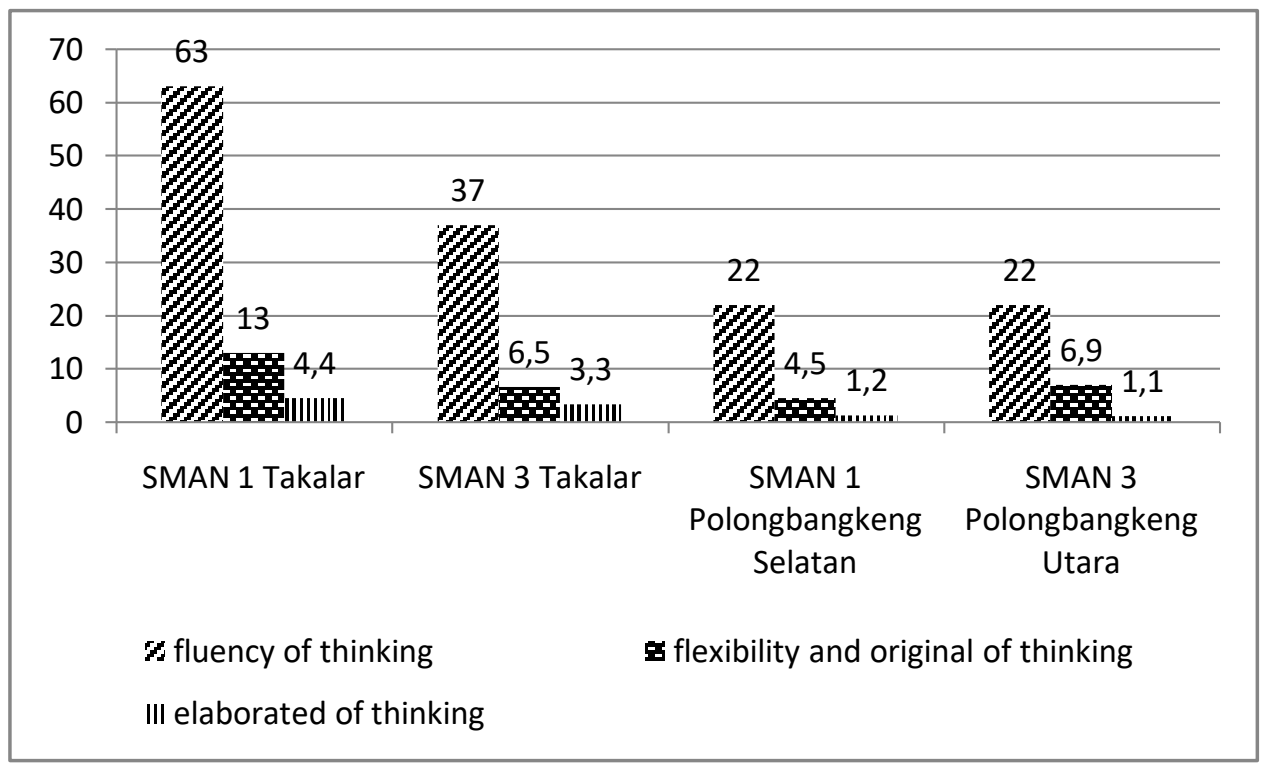


Figure 2. average value for each aspect of the verbal creative thinking abilities at each school

\subsubsection{Correlation between prior knowledge and creative thinking ability}

From the data processing, the coefficient correlation between prior knowledge and creative thinking ability using the technique of Perason Product Moment correlation is 0.619 and the significance value $0.000<\alpha$. It means that the presented hypothesis is accepted or there is a relationship between prior knowledge with creative thinking ability of students.

Regression analysis showed that the value of the variable constant prior ability and the creative thinking ability is 18,885 and the value of the regression coefficient is 0.556 . Thus, the pattern of the relationship between prior ability and creative thinking ability can be expressed in the equation of the regression line:

$\hat{\mathrm{Y}}=18,885+0,556 \mathrm{X}_{1}$

\subsection{Discussions}

The result of analysis descriptive showed that the prior knowledge of Takalar learners in middle category. Results of these studies illustrate that learners in Takalar have enough in terms of having the ability to remember, understand, and apply their knowledge to gain further knowledge.

Based on the analysis the average value of each aspect of prior knowledge, it is known that the aspect understanding has the highest average and aspect remembering has the lower average. This value indicates that learners in Takalar have the ability to understand more than the ability to remember. Of the four schools that were visited during the study, the average value of the achievement of every aspect of the prior knowledge at excellent schools are located in the city is higher than the not excellent school that is outside the city. The result of analysis descriptive also showed that creative thinking ability of learners in Takalar in middle category and aspect fluency of thinking has highest average and elaborate of thinking has lower average. It means that the learners in Takalar has fluency of thinking. Each school has different average value of every aspect of creative thinking ability, but the excellent school are located in the city is higher than not excellent school in outside the city. This is because the excellent schools which are located in the city made study groups and tutoring while the not excellent school is located outside the school, no tutoring. The tutoring is affecting the ability of learners because learners will learn so much practice and further develop their prior knowledge. The result of this study same with the result of study was done by Anwar and Rasool (2012) who states that the students come from the city has the ability to think creatively better than the students come from outside the city.

The results of analysis correlation showed that there is a relationship between the prior ability with creative thinking ability. The coefficient correlation between 
these variables is 0.619 . This value indicates that the direction of the relationship between prior knowledge and creative thinking ability is positive. It means that the learner who have higher prior knowledge, have higher creative thinking ability. Conversely, learner who have lower prior knowledge, have lower creative thinking ability.

The results of regression analysis, indicating that the pattern of the relationship between the variables of pror knowledge with creative thinking ability is $\mathrm{Y} 1=18.885+0.556 \mathrm{X} 1$. The pattern of the regression equations provide information that every one unit change in the score of prior ability leads to changes creative thinking ability score of 0.556 . In addition, the coefficient of determination ( $\mathrm{R}$ square) between the two variables is 0.384 . This value gives the sense that $38.4 \%$ variance of the variables the creative thinking abilities explained by prior ability variables and $62.6 \%$ influenced by other variables.

The results of the analysis of the average value for each aspect of the initial capabilities and aspects of creative thinking abilities, found that at the beginning prior knowledge variables, aspects of understanding has an average value of the highest among other aspects, while the variable creative thinking ability, aspects of fluency of thinking has an average value of the most high. If the terms of these aspects, it can be said that there are relationship between prior knowledge and verbal creative thinking abilities because aspect understanding in prior ability will be make the students more fluent in expressing the word or phrase that instructure in verbal creativity test.

\section{Conclusion}

There is a relationship between prior knowledge with creative thinking ability in chemistry.

\section{References}

Al-Hajjaj, Yusuf Abu. 2010. Kreatif atau Mati. Solo: Ziyad Visi Media.

Anwar, Nadeem Muhammad \& Rasool, Sahibzada, Shamin. 2012. A Comparison of Creative Thinking Abilities of High and Low Achievers Secondary School Student. International Interdeciplinary Journal of Education (Online), Volume 1, Issue 1. (http://www.google.com_A_Comparison_of_Creative_Thinking_Abilities_of_ High_and_Low_Achievers_Secondary_School_Students, diakses tanggal 23 Agustus 2013).

Cameroon \& Bryan. 1992. Meniru Kreativitas Tuhan. Jakarta: Erlangga.

Groncher, Andrea., Johri, Aditya., Kothaneth Shreya., dan Lohani Vinod. 2009.

Exploration and Exploitation in Engineering Design: Examining the Effects of Prior Knowledge on Creativity and Ideation. Online Journals.

(Online),Https://www.academia.eduExploration_and_exploitation_in_enginee ring_design_Examining the effects_of_prior_knowledge_on_creativity_and_ $i$ deation, diakses tanggal 16 Desember 2013. . 
Mariati. 2006. Pengembangan Kreativitas Siswa Melalui Pertanyaan Divergen pada Mata Pelajaran Ilmu Pengetahuan Alam (IPA). Jurnal Pendidikan dan Kebudayaan,063 (12), 759-773).

Mulyasa, Enco. 2009. Kurikulum Tingkat Satuan Pendidikan. Jakarta: Bumi Aksara.

Munandar, Utami. 2009. Pengembangan Kreativitas Anak Berbakat. Jakarta: Rineka Cipta.

Prawiradilaga, Dewi Salma. 2009. Prinsip-Prinsip Desain Pembelajaran. Jakarta: Prenada Media Group.

Purwanto, 2011. Statistika untuk Penelitian. Yogyakarta: Pustaka Pelajar.

Raehana, Sitti. 2013. Pengaruh Regulasi Diri, Motivasi Berprestasi, Iklim Keluarga, dan Efikasi Diri terhadap Prestasi Belajar Matematika Siswa Kelas X SMA Negeri di Kota Makassar. Tesis. Tidak ditebitkan. Program Pascasarjana Program Studi Pendidikan Matematika. Universitas Negeri Makassar.

Sanjaya, Wina. 2012. Strategi Pembelajaran Berorientasi Standar Proses Pendidikan. Jakarta: Kencana Prenada Media Grup.

Semiawan, Conny R, Putrawan Made, dan Setiawan. 2004. Dimensi Kreatif dalam Filsafat Ilmu. Bandung: Remadja Karya.

Sugiyono. 2009. Statsistik Penelitian Pendidikan. Jakarta: Alfa Beta. . 2011. Stastistik untuk Penelitian. Jakarta: Alfa Beta.

Suharnan. 2005. Psikologi Kognitif. Surabaya: Srikandi.

Uyanto, Stanislaus S. 2009. Pedoman Analisis Data dengan SPSS. Yogyakarta: Graha Ilmu.

Uno, Hamzah B. 2012. Orientasi Baru dalam Psikologi Pembelajaran. Jakarta: Bumi Aksara.

Walgito, Bimo. 2004. Pengantar Psikologi Umum. Yogyakarta: Andi.

Widyastono, Herry. 2009. Mengembangkan Kreativitas Peserta Didik dalam Pembelajaran. Jurnal Pendidikan dan Kebudayaan, Vol 15., No. 6 (10191033).

Yaumi, Muhammad. 2013. Prinsip-Prinsip Desain Pembelajaran. Jakarta: Kencana Prenada Media Grup. 


\section{Manuscripts with Decisions}

\begin{tabular}{lll}
\hline ACTION & STATUS & TITLE \\
\hline ADM: Karakose, Turgut & $\begin{array}{l}\text { EDUPIJ- } \\
2017-0013\end{array}$ & $\begin{array}{l}\text { The Relationship Between Prior Knowledge and } \\
\text { Creative Thinking Ability in Chemistry } \\
\text { View Submission }\end{array}$ \\
$\begin{array}{l}\text { Accept (25- } \\
\text { Jul-2017) }\end{array}$ & \\
Awaiting & \\
Production & \\
Checklist &
\end{tabular}

Publication of Ansari Saleh Ahmar:

1. Ahmar, (2013). MS Modifikasi CMS Template $\quad$ Lokomedia.

Yogyakarta: Garudhawaca.

2. Ahmar, A. S., Guritno, S., \& Stats, M. (2013). Pendeteksian dan Pengoreksian Data Yang Mengandung Additive Outlier (AO) pada Model ARIMA $(p, d, q)$ (Doctoral dissertation, [Yogyakarta]: Universitas Gadjah Mada).

3. Rahman, A., \& Ahmar, A. S. (2016). Exploration of mathematics problem solving process based on the thinking level of students in junior high school. http://files.eric.ed.gov/fulltext/EJ1115935.pdf

4. Ahmar, A. S., Rahman, A., Arifin, A. N. M., \& Ahmar, A. A. (2017). Predicting movement of stock of "Y" using Sutte indicator. Cogent Economics \& Finance, 5(1), 1347123.

5. Ahmar, A. S. (2012). Panduan Sistem Informasi Akademik Sekolah Berbasis Web. Yogyakarta: Lokomedia.

6. AHMAR, A. S. (2017). Sutte Indicator: an Approach to Predicting the Direction of Stock Market Movement. Songklanakarin Journal of Science and Technology (SJST).

7. Arsyad, M., Ihsan, N., Tiwow, V. A., \& Ahmar, A. S. Model of Groundwater Flow Using Boltzmann Lattice-Gas Automation Method In Maros Karst Region, Indonesia. http://www.drink-water-eng-sci-discuss.net/dwes-2016-9/dwes2016-9.pdf

8. Ahmar, A. S., \& Rahman, A. (2017). Development of teaching material using an Android. https://www.researchgate.net/profile/Ansari_Ahmar/publication/313861154 Development of teaching material using a n Android/links/58ac050faca27206d9bf8439/Development-of-teaching-material-using-an-Android.pdf

9. Rahman, A., Ahmar, A. S., \& Rusli, R. (2016). The Influence of Cooperative Learning Models on Learning Outcomes Based on Students' Learning Styles.

10. Ahmar, A. S. (2016). Predicting Movement of Stock of Apple Inc. using Sutte Indicator. https://ssrn.com/abstract $=2967947$

11. Rahman, A., \& Ahmar, A. S. (2016). IT-Based Tools for Development of Teaching Materials. https://ssrn.com/abstract=2967949

12. Ahmar, A. S. (2015). Sutte Indicator. https://ssrn.com/abstract=2846923

13. Ahmar, A. S. (2017). Sutte Indicator: A Technical Indicator in Stock Market. https://ssrn.com/abstract=2924309

14. Rahman, A., \& Ahmar, A. S. (2017). Educational Process: International Journal.

15. Ahmar, A. S., Rusli, R., \& Rahman, A. (2017). Steps in Designing Queue and Interview Process using Information System: A Case of Re-registration of New Students in Universitas Negeri Makassar. Jurnal Internasional, 9(1), 52-57.

16. Rahman, A., \& Ahmar, A. S. (2017). Relationship between learning styles and learning achievement in mathematics based on genders.

17. Mulbar, U., Rahman, A., \& Ahmar, A. S. (2017). Analysis of the ability in mathematical problem-solving based on SOLO taxonomy and cognitive style.

18. Arsyad, N., Rahman, A., \& Ahmar, A. S. (2017). Developing a self-learning model based on open-ended questions to increase the students' creativity in calculus. Global Journal of Engineering Education, 9(2), 143-147.

19. AHMAR, A. S. (2017). SuIndiWeb: a web-based platform of sutte indicator to predicting movement of stock.

20. Ahmar, A. S. Panduan eLearning untuk Mahasiswa.

21. Ahmar, A. S. Tutorial Citation and Reference Manager dengan Mendeley. - 